\title{
Features of self-presentation of modern young people in social networks
}

\author{
Irina Abakumova ${ }^{1}$, Zinaida Brizhak ${ }^{2}$, Anna Kukulyar ${ }^{1}$, and Anastasia Kolenova ${ }^{1, *}$ \\ ${ }^{1}$ Don State Technical University, 344003, Gagarin sq., 1, Rostov on Don, Russia \\ ${ }^{2}$ Rostov State Medical University; 344022, Department of «Medical Law», Rostov-on-Don, Russian \\ Federation, Nakhichevan ave, 29
}

\begin{abstract}
In the digital age of a transitive society, interaction between people is undergoing significant changes. Many researchers talk about the virtualization of modern society, in which visual communication comes to the fore. However, despite the prevalence of the above-mentioned processes, questions remain about strategies for presenting themselves to society using social networks, and how people position themselves when publicly presenting themselves in an online environment. As part of the empirical study, the object was 30 boys and 30 girls, representatives of modern youth who actively use social networks. The age of the subjects is from 14 to 17 years. We used four test methods: the "Who am I" Method of Kuhn and McPortland; the "Scale of self-presentation tactics" by S.J. Li in the adaptation of Pikuleva O.A.; "Scale of perfectionist selfpresentation" By P. Hewitt in the adaptation of Zolotareva A.A.; "Test of self-confidence" by V.G. Romek. The theoretical and practical significance of the research lies in the development of ideas about the specifics of selfpresentation of modern youth who actively use social networks. The results of the study can be used in the practice of family and individual counseling of parents and adolescents, as well as in teachers and psychologists of various educational institutions.
\end{abstract}

\section{Introduction}

No social interaction is complete without presenting oneself, ones personal, professional or other qualities. Self-presentation is an integral part of life in modern society. As technological progress develops, a new form of social reality is created, in which online interaction practices play an important role. The individual has a need to represent himself in this new space, in particular, in social networks. The features of online interaction, which include a wide range of opportunities for creating their own identity, endow the individual with ample opportunities for self-presentation of himself to other participants in the online space. In particular, one of the most popular self-presentation tools are personal photos and information posted on the personal pages of social media participants $[1-5,14,18,20]$.

Based on the indicated problem, we consider it expedient to rely on the following theoretical approaches to the study of the features of self-presentation in the Internet: I.R.

\footnotetext{
* Corresponding author: kolenova.nastya@yandex.ru
} 
Abitov, I.I. Babaeva, I.V. Burmistrov, V.L. Volokhonskiy, T.A. Kubrak, Yu.V. Fomicheva, A.G. Shmelev and others, as well as B. Becker, Sh. Buhler, J. Binder, M. Griffiths, D. Kuss, Sh. Turkle, S. Jun, E. Tsoi and others. The study of the foundations of selfpresentation was carried out by: O.K. Agavelyan, G.V. Borozdin, P.N. Ermakov, V.A. Labunskaya, E.V. Mikhailova, Yu.O. Obukhova, O. A. Pikuleva, D. S. Pogontseva, S.G. Rusinova, L.B. Filonov, I.P. Shkuratova, et al., As well as R. Arkin, R. Baumeister, R. Wickland, G. Gleitman, I. Goffman, I. Jones, R. Kowalski, T. Leary, D. Myers, T. Pittman, M. Ries, M. Snyder, A. Steinhilber, J. Tedeshi, V. Schlenker, A. Schutz and others [4-19].

\section{Discussion}

Today, the question of self-presentation becomes relevant for consideration, that is any act of self-expression, the ability to present oneself from the advantageous side, the process of controlling external impression. Let us also note the fact that the relevance of studying the issue of self-presentation is connected with the fact that any interpersonal interaction cannot do without the presentation of ones "I". The solution to various problems of effective interpersonal interaction, which is understood as the personal and professional development of an individual, is directly related to self-presentation [6-14, 18, 20].

We also consider it important to note that any interpersonal interaction is communicative in nature, while it is necessary to take into account the need to attract the attention of others with the subsequent management of impressions about oneself. The need for ones own modeling and formation of the desired image is becoming more and more obvious. Modern research in the framework of motivational (R. Arkin, A. Bass, R. Wickland, M. Weigold, G. Gleitman, I. Goffman, R. Kowalski, C. Cooley, M. Leary, D. Myers, J. G. Mead, M. Snyder, L. Festinger, L.B. Filonov, F. Haider, M. Scherier, B. Schlenker, A. Schutz) and situational (R. Baumeister, G. V. Borozdina, I. Jones, Yu M. Zhukov, T. Pittman, M. Ries, A. Steichilber, J. Tedeshi) theories and concepts allow us to assert that self-presentation is due to both internal and external evaluations. Many authors of various theories of self-presentation support the opinion that the ability to manage oneself, ones emotions, the manifestations of ones feelings is not only developed to various degrees in individuals, but also depend on the personality characteristics of a person (these include motivation, type of character, level of self-awareness) [1- 4].

Nowadays, there are several stereotypes regarding the definition of self-presentation. However, it is customary to believe that this definition is understood as self-presentation of ones "I", which can manifest itself consciously or unconsciously, purposefully or spontaneously, this is not so important, the main thing is that the manifestation occurs when interacting with people around. Self-presentation also plays an important role in the youth environment. This theory is supported by various studies that demonstrate how a teenager identifies himself and members of the youth group. A special place in these studies is occupied with works aimed at studying the behavior of adolescents in the virtual space.

Self-presentation in a virtual environment has several differences. The first difference that can be noted is that in social interaction in real conditions, the adolescent is somewhat limited in his ability to manage information about himself within the framework of the sex, appearance, signs of social status, profession, nationality, and age that the interlocutor actually perceives. However, on the other hand, during a virtual self-presentation, the same teenager has an almost unlimited opportunity to control the impression of himself $[5,14$, 15-20].

For adolescents, perception of virtual and real space, a more blurred boundary is characteristic; they put a personal meaning in what is happening on the Internet. In this regard, at some point in life for a teenager, communication in the Internet space can replace 
real communication, and scientists in this case highlight both positive and negative consequences of such an alternative [19].

\section{Research methods and techniques}

In the course of an empirical research to study the characteristics of self-presentation of modern youth in social networks, we used the following methods: 1. Who am I; by Kuhn and McPortland; 2. "Scale of self-presentation tactics" by S. Zh. Li (adapted by O.A. Pikuleva); 3. "Scale of perfectionist self-presentation" by P. Hewitt (adapted by A.A. Zolotareva); 4. Test of self-confidence; V.G. Romeka. The object of the study were 30 guys and 30 girls, representatives of modern youth who actively use social networks (VKontakte, Instagram, TikTok). The age was from 14 to 17 years. All the respondents were divided into 2 groups: group 1 - boys ( 30 people), group 2 - girls (30 people).

Research hypotheses: 1. There may be differences in the characteristics of selfpresentation among boys and girls in social networks. 2. Presumably, representatives of the modern youth are guided by the image of the "ideal I", carrying out self-presentation in social networks.

\section{Research results}

According to the results of the test "Who am I" by Kuhn and McPortland, it was revealed that there are differences in the perception of their personality type, both among boys and girls. For all groups of respondents, the leading personality type is "Balanced". At the same time, it is worth noting that, despite the desire of the respondents to assess themselves adequately, the "Emotionally polar" and "Doubting personality types" reached almost equal values. In the group of girls, the emotionally polar type prevails, and in the group of boys, the doubting personality type is more common.

To constantly assess themselves, their condition, comparing with ideal ideas, etc. is in need for most of the young people, both in the group of boys and in the group of girls (21 people $-70 \%$ ), and in the group of girls (24 people - 80\%). At the same time, some respondents have observed its peak manifestation - crisis self-reflection, which indicates the excessiveness of negative doubts and the presence of general high anxiety among these respondents (1 guy and 3 girls). Lack of self-reflection is observed only among 8 guys $13.3 \%$ and 3 girls $-5 \%$.

Of all the five indicators of gender-role identification among young people, indicators were diagnosed only for "Neutral identity" among 12 boys - 20\% and 8 girls $-13.3 \%$ and "Emotionally positive identity" among 18 guys - 30\% and 22 girls $-36.6 \%$. Boys strive to fulfill a social role associated with relationships with activities; the second social role is the physical social role (strong, pleasant, attractive, and description of appearance). The social role of the third order is the communication process. The least significant are: the social role in the family and features of future prospects.

For a group of girls, the leading is a physical social role (a subjective description of their physical data and appearance). Activity is second in importance. The social roles of girls, which are associated with the role in the family and the process of communication, have reached equal values. The least significant is the social role associated with further prospects or relationships with the opposite sex.

The highest level of personality differentiation is observed in the group of girls (22 people $-73.4 \%$ ), which indicates the need to carefully and in detail describe oneself and one's life. In the group of boys, the average level of personality differentiation prevails (21 people $-70 \%$ ), reflecting adequate self-esteem and description of their personality. 
However, statistically significant differences among the 2 groups were obtained only with respect to self-reflection, the underlying level of self-esteem, adaptability and personality integrity (Table 1).

Table 1. Statistically significant differences among the 2 groups were obtained only with respect to self-reflection, the underlying level of self-esteem, adaptability and personality integrity

\begin{tabular}{|c|c|c|c|c|}
\hline \multirow{2}{*}{$\begin{array}{c}\text { Results of the } \\
\text { test } \\
\text { «Who am I?» }\end{array}$} & \multicolumn{2}{|c|}{ Research groups (Mean Rank) } & \multirow{2}{*}{$\begin{array}{c}\mathrm{U}- \\
\text { criteria }\end{array}$} & \multirow{2}{*}{$\begin{array}{l}\text { Level of } \\
\text { importance }\end{array}$} \\
\hline & $\begin{array}{c}\text { 1st group (boys) } \\
\mathbf{N}=30 \text { people }\end{array}$ & $\begin{array}{c}\text { 2nd group (girls) } \\
\mathrm{N}=30 \text { people }\end{array}$ & & \\
\hline \multicolumn{5}{|c|}{ Self-reflection } \\
\hline absent & 26.6 & 10 & 942.6 & 0,000 \\
\hline present & 70 & 80 & 483.4 & 0,037 \\
\hline crisis & 3.4 & 10 & 849.3 & 0,000 \\
\hline
\end{tabular}

As a result of the analysis of the primary data on the "Tactics of self-presentation" by $S$. Zh. Li (adaptation of O. Pikuleva), it was revealed that in the group of girls almost all the tactics of self-presentation are used in social networks. Only the "Self-deprecation" tactic is not used. The leading tactics in this group are "Attractive behavior" (13 people - 43.3\%) and "Self-aggrandizement" (10 people - 33.3\%). In the group of boys, only 2 basic tactics of self-presentation are used: "Self-promotion" (16 people - 53.3\%) and "Attractive behavior" (14 people - 46.6\%). Statistically significant differences among the 2 groups regarding the tactics of self-presentation among young people in social networks are shown in the table 2 .

Table 2. Statistically significant differences among the 2 groups regarding the tactics of selfpresentation among young people in social networks

\begin{tabular}{|c|c|c|c|c|}
\hline \multirow[b]{2}{*}{$\begin{array}{l}\text { Self-presentation } \\
\text { tactics }\end{array}$} & \multicolumn{2}{|c|}{ Research groups (Mean Rank) } & \multirow[b]{2}{*}{$\begin{array}{c}\mathrm{U}- \\
\text { criteria }\end{array}$} & \multirow{2}{*}{$\begin{array}{c}\text { Level of } \\
\text { importanc } \\
\mathrm{e} \\
\end{array}$} \\
\hline & $\begin{array}{c}\text { 1st group (boys) } \\
\mathbf{N}=30 \text { people }\end{array}$ & $\begin{array}{c}\text { 2nd group (girls) } \\
\mathrm{N}=30 \text { people }\end{array}$ & & \\
\hline Attractive behavior & 46.6 & 43.3 & 234.6 & 0.042 \\
\hline Self-exaltation & 16 & 10 & 787.5 & 0.017 \\
\hline
\end{tabular}

As a result of research using the methodology "Scale of perfectionist self-presentation" by P. Hewitt, adapted by A.A. Zolotareva, the following results were obtained. The leading subscale of perfectionist self-presentation for both boys and girls is "Demonstration of Excellence". However, girls on the subscales "Behavioral non-manifestation of imperfection" and "Verbal non-manifestation of imperfection" have a higher representation than boys. Statistically significant differences among the 2 groups regarding the subscales of perfectionist self-presentation are shown in the figure 3.

According to the "Test of self-confidence" by Romek V.G. in the group of boys, a fairly high level of self-confidence can be noted. Along with this, boys show an average level of initiative in social contacts, limiting themselves to their usual circle of contacts in social networks and everyday life. In the group of girls, the manifestation of social courage prevails, which reflects the presence of predominantly emotional processes accompanying the choice of one or another alternative of behavior and arising when it is necessary to assess their own skills and abilities. Statistically significant differences among the 2 groups regarding the components of self-confidence are shown in the table 4 .

Table 3. Statistically significant differences among the 2 groups regarding the subscales of perfectionist self-presentation 


\begin{tabular}{|c|c|c|c|c|}
\hline \multirow[b]{2}{*}{$\begin{array}{l}\text { Self-presentation } \\
\text { tactics }\end{array}$} & \multicolumn{2}{|c|}{ Research groups (Mean Rank) } & \multirow[b]{2}{*}{$\begin{array}{c}\text { U- } \\
\text { criteria }\end{array}$} & \multirow{2}{*}{$\begin{array}{c}\text { Level of } \\
\text { importan } \\
\text { ce }\end{array}$} \\
\hline & $\begin{array}{c}1 \text { st group (boys) } \\
\mathrm{N}=30 \text { people }\end{array}$ & $\begin{array}{c}\text { 2nd group (girls) } \\
\mathbf{N}=30 \text { people }\end{array}$ & & \\
\hline $\begin{array}{c}\text { Demonstration of } \\
\text { excellence }\end{array}$ & 83.3 & 66.6 & 968.7 & 0.001 \\
\hline $\begin{array}{l}\text { Behavioral non- } \\
\text { manifestation of } \\
\text { imperfection }\end{array}$ & 13.3 & 20 & 475.3 & 0.018 \\
\hline $\begin{array}{l}\text { Verbal non- } \\
\text { manifestation of } \\
\text { imperfection }\end{array}$ & 6.6 & 13.3 & 589.8 & 0.021 \\
\hline
\end{tabular}

Table 4. Statistically significant differences among the 2 groups regarding the components of selfconfidence

\begin{tabular}{|c|c|c|c|c|}
\hline \multirow[b]{2}{*}{$\begin{array}{l}\text { Constituents of } \\
\text { self-confidence }\end{array}$} & \multicolumn{2}{|c|}{ Research groups (Mean Rank) } & \multirow{2}{*}{$\begin{array}{c}\text { U- } \\
\text { Criteria }\end{array}$} & \multirow{2}{*}{$\begin{array}{c}\text { Level of } \\
\text { importance }\end{array}$} \\
\hline & $\begin{array}{c}\text { 1st group (boys) } \\
\mathbf{N}=\mathbf{3 0} \text { people }\end{array}$ & $\begin{array}{c}\text { 2nd group (girls) } \\
\mathbf{N}=30 \text { people }\end{array}$ & & \\
\hline $\begin{array}{l}\text { Self-confidence / } \\
\text { self-doubt }\end{array}$ & 8.2 & 6.4 & 452.4 & 0.042 \\
\hline $\begin{array}{c}\text { Social courage / } \\
\text { shyness }\end{array}$ & 7.5 & 7.9 & 263.2 & 0.023 \\
\hline $\begin{array}{c}\text { Social } \\
\text { networking } \\
\text { initiative }\end{array}$ & 5.7 & 6.8 & 471.6 & 0.036 \\
\hline
\end{tabular}

\section{Conclusion}

1. There are differences in the perception of their personality type, both for boys and girls. For all groups of respondents, the leading personality type is "Balanced". At the same time, it is worth noting that, despite the desire of the respondents to assess themselves adequately, the "Emotionally polar" and "Doubting personality types" reached almost equal values. In the group of girls, the emotionally polar type prevails, and in the group of boys, the doubting personality type is in common.

2. Most of the young people are in need of constant assessment of themselves, their condition, comparison with ideal ideas, etc., both in a group of boys and in a group of girls. At the same time, some respondents have observed its peak manifestation - crisis selfreflection, which indicates the excessiveness of negative doubts and the presence of a general high anxiety among these respondents. Lack of self-reflection is observed among only a small number of young people.

3. Of all five indicators of gender-role identification among young people, only indicators for "Neutral identity" were diagnosed.

4. Primarily, boys strive to fulfill a social role associated with relationships with activities (occupations, activities, interests, hobbies, self-esteem of achievements); the second social role is the physical social role (strong, pleasant, attractive, and description of appearance). The social role of the third order is the communication process (friendship, perception of oneself as a member of a group of friends, as well as communication or a subject of communication, features and assessment of interaction with people). The least significant are: the social role in the family (son, brother) and features of future prospects (professional perspective: wishes, intentions, dreams associated with the educational and professional sphere).

5. For a group of girls, the leading is a physical social role (a subjective description of their physical data and appearance). The second most important is activity (occupation, activity, 
interests, hobbies, self-assessment of achievements). The social roles which are associated with the role in the family (daughter, granddaughter, sister) and the communication process (friendship, perception of oneself as a member of a group of friends, as well as communication or a subject of communication, features and assessment of interaction with people) of girls reached equal values. The least significant is the social role associated with further prospects or relationships with the opposite sex.

6. The highest level of personality differentiation is observed in the group of girls, which indicates the need to carefully and in detail describe themselves and their lives. In the group of boys, the average level of personality differentiation prevails, reflecting an adequate selfesteem and description of their personality. At the same time, it should be noted that indicators of a low level of personality differentiation, indicating increased anxiety, closeness and corresponding to an intrapersonal crisis, were not found among young people.

7. The general valence of identity for a group of boys can be characterized by a neutral and positive assessment of oneself with insignificant indicators on the "Overestimated valence" scale. Interesting results were found in the subgroup of girls, where there is a "Positive" and "Overestimated" general identity valence. "Neutral" and "negative" identity valences were not revealed among young people.

8. In a group of girls, almost all tactics of self-presentation in social networks are used. Only the "Self-deprecation" tactic is not used. The leading tactics in this group are "Attractive behavior" and "Self-aggrandizement". In a group of boys, only 2 basic tactics of self-presentation are used: "Self-promotion" and "Attractive behavior". Just like girls, boys use these tactics of self-presentation to the full extent of their strategies.

9. The leading subscale of perfectionist self-presentation for both boys and girls is "Demonstration of Excellence". However, girls on the subscales "Behavioral nonmanifestation of imperfection" and "Verbal non-manifestation of imperfection" have a higher representation than boys.

10. In the group of boys, a fairly high level of self-confidence can be noted. Along with this, boys show an average level of initiative in social contacts, limiting themselves to their usual circle of contacts in social networks and everyday life. In the group of girls, the manifestation of social courage prevails, which reflects the presence of predominantly emotional processes accompanying the choice of one or another alternative of behavior and arising when it is necessary to assess their own skills and abilities.

11. In the course of statistical processing of data using the Man-Whitney U-test, we obtained significant differences in the characteristics of self-presentation of young people in social networks.

As a result of the research, we can confidently conclude that hypothesis 1 that there may be differences in the characteristics of self-presentation among boys and girls in social networks has been fully confirmed. Hypothesis 2, that, presumably, representatives of modern youth are guided by the image of the "ideal I", carrying out self-presentation in social networks, has been fully confirmed.

This research was funded by the Russian Foundation for Basic Research (RFBR), project № 1829-22004.

\section{References}

1. I. V. Abakumova, I. A. Bakaeva, K. Y. Kolesina, Technologies of initiating students into independent (self-guided) activity in supplementary distance learning. International Journal of Cognitive Research in Science, Engineering and Education. (2016). 
2. I. V. Abakumova, P. N. Ermakov, M. V. Godunov, Polar meaning-building strategies: Acmeological characteristics. Psychology in Russia: State of the Art. (2018)

3. I. V. Abakumova, I. Bakaeva, A. Grishina, E. Dyakova, Active learning technologies in distance education of gifted student. International Journal of Cognitive Research in Science, Engineering and Education. (1)7, 85-94 (2019)

4. M. Daniel, J. Sinanan, Visualising Facebook (London, UCL Press, 2017)

5. S. Diefenbach, L. Christoforakos, The Selfie Paradox: Nobody Seems to Like Them Yet Everyone Has Reasons to Take Them. An Exploration of Psychological Functions of Selfies in Self-Presentation. http://journal.frontiersin.org/article/10.3389/fpsyg.2019. 00007/full\#h8 (2019)

6. M. A. Erofeeva, A. A. Fedorov, Production and consumption of images in the digital age (2019) http://cyberleninka.ru/article/n/proizvodstvo-i-potreblenie-izobrazheniy-vtsifrovuyu-epohu (Last accessed 16.06.2020)

7. D. S. Gvozdikov, Under the influence of the network: an anthropological approach to analyzing the formation of online connections. Bulletin Of St. Petersburg State University, 12(2), (2014) http://cyberleninka.ru/article/n/pod-vliyaniem-setiantropologicheskiy-podhod-k-analizu-formirovaniya-online-svyazey (Last accessed 23.07.2020)

8. O. A. Grimov, Self-presentation and self-identification of a person in social networks http://www.rusnauka.com/6_PNI_2013/Psihologia/12_129127.doc.htm (Last accessed 28.07.2020)

9. M. Leary, J. P. Tangney, Handbook of Self and identity. Second Edition. New York. 754 (Last accessed 25.07.2020)

10. Yu. O. Obukhova, Mobile phone as a means of self-presentation in interpersonal communication. Journal of sociology and social anthropology, 14(2), 119-138 (2011)

11. O. A. Pikuleva, Psychology of personality self-presentation: gender and age aspects. Psychological science and education, (3), 37-43 (2014)

12. E. Pearson, Making a Good (Virtual) First Impression: The Use of Visuals in Online Impression Management and Creating Identity Performances https://hal.inria.fr/hal01058173/document (Last accessed 29.07.2020)

13. J. Rui, M. A. Stefanone, Strategic self-presentationonline: A cross-cultural study.http://www.buffalo.edu/content/dam/cas/communication/files/Stefanone/RuiCH B2013.pdf (Last accessed 03.08.2020).

14. A. Siibak, Reflections of RL in The Virtual World. Cyberpsychology: Journal of Psychosocial Research on Cyberspace. http://cyberpsychology.eu/view.php?cisloclanku $\quad=2007072301 \&$ article $=1 \quad$ (Last accessed 03.08.2020)

15. I. P. Shkuratova, Yu. A. Gotseva, Self-Representation of teenagers in interpersonal communication.

https://irshkuratova.ru/files/samopredjavlenie_podrostkov_v_obshenii.pdf （Last accessed 03.08.2020)

16. O. V. Shuster, Visuality as a global trend in the space of mass media. http://www.erjournal.ru/journals_n/1375549519.pdf(Last accessed 05.08.2020)

17. E. Vasina, Self-Presentation of an individual in the network: features of language games. https://e.mail.ru/attachment/14819675240000000722/0;1 (Last accessed 03.07.2020) 
18. E. Vorobyeva, V. V. Kosonogov, E. M. Kovsh, P. N. Ermakov, I. Abakumova, Yu. I. Motalova, Overcoming the barriers against learning which are rooted in different understanding of the emotional expression in people of russian and armenian ethnic identities. INTED2019 13th International Technology, Education and Development Conference Conference proceedings 5958-5963 (2019)

19. A. E. Zhichkina, E. P. Belinskaya, Strategies of self-presentation in the Internet and their connection with real identity. http://banderus2.narod.ru/70312.html (Last accessed 13.07.2020)

20. A. A. Zolotareva, Perfectionist self-presentation and features of its diagnostics. Clinical psychology and special education, (7)1, 104-117 (2018) 